\title{
A short and efficient synthesis of valsartan via a Negishi reaction
}

\author{
Samir Ghosh, A. Sanjeev Kumar and G. N. Mehta*
}

\section{Full Research Paper}

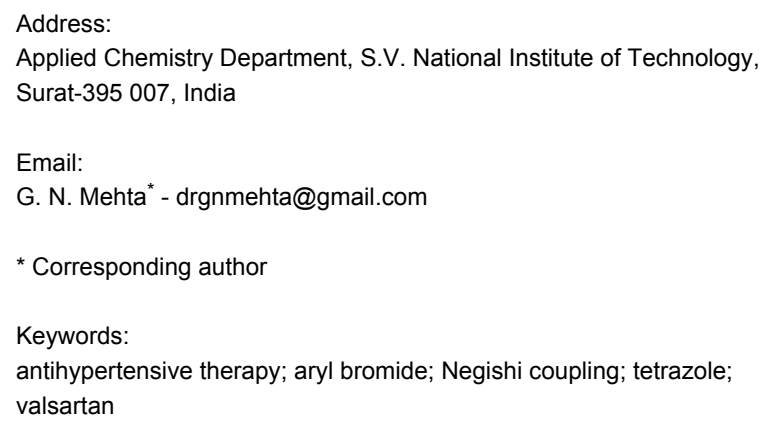

Beilstein Journal of Organic Chemistry 2010, 6, No. 27 doi:10.3762/bjoc.6.27

Received: 21 January 2010

Accepted: 10 March 2010

Published: 18 March 2010

Associate Editor: I. Marek

(c) 2010 Ghosh et al; licensee Beilstein-Institut. License and terms: see end of document.

\section{Abstract}

An efficient synthesis of the angiotensin-II inhibitor valsartan (Diovan $\left.{ }^{\circledR}\right)$ is presented. Directed ortho-metalation of 5-phenyl-1trityl- $1 H$-tetrazole (6) and its Negishi coupling with aryl bromide $\mathbf{5}$ are the key steps of the synthesis. This method overcomes many of the drawbacks associated with previously reported syntheses.

\section{Introduction}

Valsartan (Figure 1) is a member of a class of compounds known as angiotensin II (AT-II) receptor antagonists. This class combines effective anti-hypertensive activity with an excellent profile of safety and tolerability. Activation of AT-II receptors in the outer membrane of vascular smooth muscle cells of the heart and arteries causes the tissues to constrict. AT-II receptors are activated by the octapeptide AT-II. AT-II helps to maintain constant blood pressure [1] despite fluctuations in a person's state of hydration, sodium intake and other physiological variables. AT-II also performs the regulatory tasks of inhibiting the excretion of sodium by the kidneys, inhibiting norephedrine re-uptake and stimulating aldosterone biosynthesis.

Valsartan [2] is therefore a non-peptide AT-II antagonist. By inhibiting the actions of AT-II on its receptors, valsartan

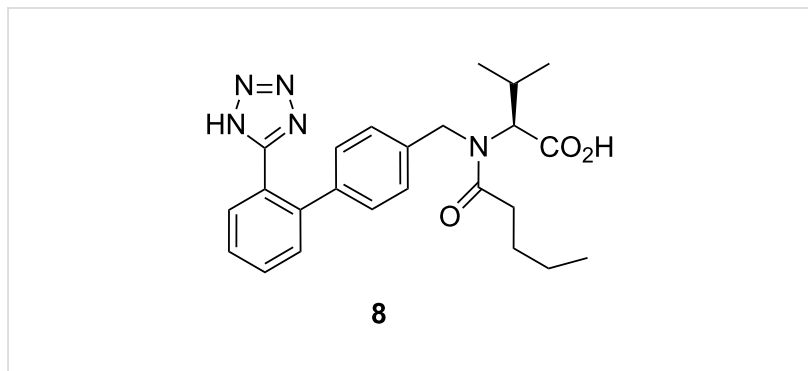

Figure 1: Valsartan.

prevents the increase of blood pressure produced by the hormone-receptor interactions. Hence, it is used in the treatment of cardiovascular complaints such as hypertension and heart failure. Comparative trial studies have shown that 
valsartan is as effective as angiotensin-converting enzyme (ACE) [3] inhibitors, calcium-channel blockers and $\alpha$-blockers, and is generally better tolerated. Valsartan is marketed as the free acid under the trade name Diovan ${ }^{\circledR}$. In addition, in combination with diuretics such as hydrochlorothiazide, valsartan offers specific advantages as an anti-hypertensive agent.

The formation of the aryl-aryl bond represents the key step in the synthesis of sartans: whilst the synthesis of losartan [4] as described in the literature makes use of Negishi $[5,6]$ and Ullmann [7] couplings, the published methods for the preparation of valsartan utilize Suzuki-Miyaura couplings [8]. Of these, Negishi reactions have proved to be very efficient. However, the use of organozinc compounds provides better transmetalation activity than that obtained by the use of organoboron reagents as well as good chemoselectivity since most common functional groups are not attacked by organozinc species. Although preparations of several biphenyl ring systems related to valsartan have been reported, a number of challenges and some disadvantages - such as tedious reaction conditions, low yields and multistep sequences - still exist. Therefore, developing an efficient synthetic strategy with fewer steps that provides diverse access to these bioactive compounds is an important goal. In this paper, we report a new, concise and efficient synthesis of valsartan via Negishi coupling.

\section{Results and Discussion}

From a retro-synthetic analysis (Scheme 1), compound $\mathbf{8}$ could be constructed via Negishi coupling from aryl bromide $\mathbf{5}$ and 5-phenyl-1-trityl-1H-tetrazole (6), which in turn could be obtained from commercially available benzonitrile. Aryl bromide 5 could be accessed by several discrete reactions of compound $\mathbf{3}$ and compound $\mathbf{4}$ via a nucleophilic substitution reaction.

As shown in Scheme 2, inexpensive and commercially readily available valeryl chloride $\mathbf{1}$ was coupled with L-valine methyl ester hydrochloride (2) in the presence of triethylamine in dichloromethane at $0{ }^{\circ} \mathrm{C}$ to afford methyl $\mathrm{N}$-pentanoyl-Lvalinate in $95 \%$ yield. Compound 3 was $\mathrm{N}$-protected with 1-bromo-4-(bromomethyl)benzene in presence of sodium hydride in tetrahydrofuran to give methyl $N$-(4-bromobenzyl)$N$-pentanoyl-L-valinate (5) [9] in 70\% yield. Ortho-metalation of 5-phenyl-1-trityl-1 $H$-tetrazole (6) [10] with $n$-butyllithium at $25{ }^{\circ} \mathrm{C}$ followed by treatment with zinc chloride at $-20{ }^{\circ} \mathrm{C}$ gave the desired organozinc chloride compound. Coupling of the latter with aryl bromide $\mathbf{5}$ in presence of a catalytic amount of Q-phos and palladium acetate in tetrahydrofuran at $75{ }^{\circ} \mathrm{C}$ produced methyl $N$-pentanoyl- $N$ - $\left\{\left[2^{\prime}-(1\right.\right.$-trityl-1 $H$-tetrazol-5yl)biphenyl-4-yl]methyl\}-L-valinate (7) in $80 \%$ yield. Hydolysis of 7 with $3 \mathrm{~N} \mathrm{NaOH}$ in methanol gave valsartan 8 [11].

\section{Conclusion}

In summary, a highly efficient approach to the biphenyltetrazole structure of the AT-II antagonists has been developed which involves Negishi coupling of metalated 5-phenyl-1-trityl$1 H$-tetrazole. The method is commercially viable and applicable to plant scale production. This approach provides an industrial viable procedure for the synthesis of valsartan.<smiles>CCCCC(=O)N(Cc1ccc(-c2ccccc2-c2nnn[nH]2)cc1)C(C(=O)O)C(C)C</smiles>

8

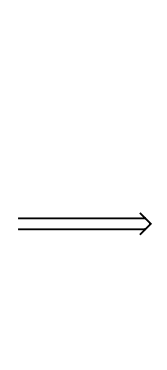<smiles>CCCCC(=O)N(Cc1ccc(Br)cc1)C(C(C)=O)C(C)C</smiles>

5<smiles>c1ccc(-c2nnnn2-c2ccccc2)cc1</smiles>

6 


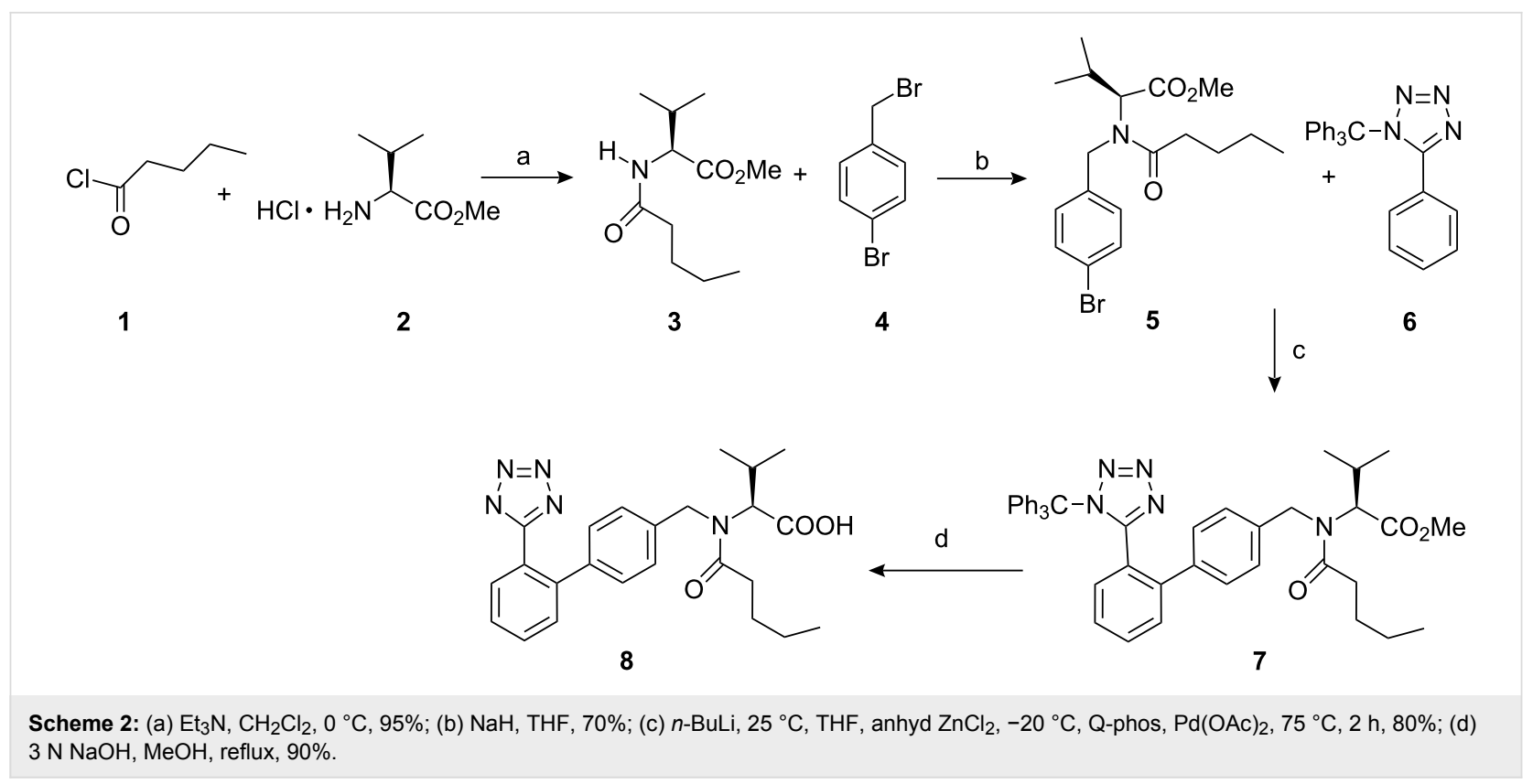

\section{Experimental}

\section{Materials and instruments}

All solvents and reagents were purchased from the suppliers and used without further purification. All non-aqueous reactions were performed in dry glassware under a dry nitrogen atmosphere. Organic solutions were concentrated under reduced pressure. Thin layer chromatography was performed on Merck precoated Silica-gel $60 \mathrm{~F}_{254}$ plates. ${ }^{1} \mathrm{H}$ and ${ }^{13} \mathrm{C}$ NMR spectra were recorded on a Varian Gemini $400 \mathrm{MHz}$ FT NMR spectrometer using $\mathrm{CDCl}_{3}$ or DMSO- $d_{6}$ as solvent. Chemical shifts are reported in $\delta \mathrm{ppm}$ relative to TMS. Mass spectra were recorded on a Shimadzu LCMS-QP 800 LC-MS and AB-4000 Q-trap LC-MS/MS.

Methyl $\mathbf{N}$-pentanoyl-L-valinate (3). Triethylamine $(8.33 \mathrm{~mL}$, $59.88 \mathrm{mmol})$ was added to a suspension of L-valine methyl ester hydrochloride $2(5.0 \mathrm{~g}, 29.94 \mathrm{mmol})$ in dichloromethane $(50 \mathrm{~mL})$. Valeryl chloride $\mathbf{1}(3.95,32.93 \mathrm{mmol})$ was then added at $0{ }^{\circ} \mathrm{C}$ and the mixture stirred at $25^{\circ} \mathrm{C}$ for $1 \mathrm{~h}$. Water $(50 \mathrm{~mL})$ was added to the reaction mixture and the organic layer separated and concentrated. The solid compound was triturated with heptanes $(50 \mathrm{~mL})$ to give an off white solid $3(6.11 \mathrm{~g}, 95 \%$ yield). $R_{\mathrm{f}}=0.6$ (7:3; heptanes/EtOAc),${ }^{1} \mathrm{H}$ NMR $(400 \mathrm{MHz}$, DMSO- $\left.d_{6}\right): \delta 8.01(\mathrm{~s}, 1 \mathrm{H}), 4.12(\mathrm{~m}, 1 \mathrm{H}), 3.59(\mathrm{~s}, 3 \mathrm{H}), 2.48(\mathrm{~m}$, $2 \mathrm{H}), 2.13(\mathrm{~m}, 2 \mathrm{H}), 1.95(\mathrm{~m}, 1 \mathrm{H}), 1.45(\mathrm{~m}, 3 \mathrm{H}), 1.25(\mathrm{~m}, 5 \mathrm{H})$, $0.86(\mathrm{~d}, J=4.4 \mathrm{~Hz}, 3 \mathrm{H}) ;{ }^{13} \mathrm{C} \mathrm{NMR}\left(100 \mathrm{MHz}, \mathrm{CDCl}_{3}\right)$ : $\delta$ 173.2, 77.4, 56.8, 52.0, 36.2, 34.9, 31.2, 27.7, 22.2, 18.8; ESIMS: $\mathrm{m} / \mathrm{z}$ calcd $[\mathrm{M}]^{+}: 215$; found: $216[\mathrm{M}+\mathrm{H}]^{+}$.

Methyl $\mathrm{N}$-(4-bromobenzyl)- $\mathrm{N}$-pentanoyl-L-valinate (5). Sodium hydride dispersion $(60 \%)$ in mineral oil $(1.83 \mathrm{~g}$,
$46.51 \mathrm{mmol}$ ) was added to a solution of compound 3 (5.0 g, $23.25 \mathrm{mmol}$ ) and 1-bromo-4-(bromomethyl)benzene (4) $(6.39 \mathrm{~g}, 25.58 \mathrm{mmol})$ in tetrahydrofuran $(80 \mathrm{~mL})$. The reaction mixture was refluxed for $1 \mathrm{~h}$. After cooling, the mixture was diluted with ether $(100 \mathrm{~mL})$ and washed successively with saturated aq $\mathrm{NH}_{4} \mathrm{Cl}(50 \mathrm{~mL})$ and water $(100 \mathrm{~mL})$. The organic layer was dried over $\mathrm{Na}_{2} \mathrm{SO}_{4}$ and concentrated in vacuum. The residue was chromatographed on silica gel. Elution with a mixture of heptanes and ethyl acetate (70:30) yielded the title compound $5(6.25 \mathrm{~g}, 70 \%)$ as a colorless oil. $R_{\mathrm{f}}=0.5(7: 3$; heptanes/ EtOAc), ${ }^{1} \mathrm{H}$ NMR (400 MHz, DMSO- $\left.d_{6}\right): \delta 7.54(\mathrm{~d}, J=6.8 \mathrm{~Hz}$, $2 \mathrm{H}), 7.29$ (d, $J=8.8 \mathrm{~Hz}, 2 \mathrm{H}), 5.01(\mathrm{~s}, 2 \mathrm{H}), 4.13(\mathrm{~m}, 1 \mathrm{H}) 3.31$ (s, 5H), $2.32(\mathrm{t}, J=14.8 \mathrm{~Hz}, 2 \mathrm{H}) 1.50(\mathrm{~m}, 2 \mathrm{H}), 1.93(\mathrm{~m}, 1 \mathrm{H})$, $1.24(\mathrm{~m}, 3 \mathrm{H}), 1.22(\mathrm{~m}, 3 \mathrm{H}), 0.83(\mathrm{~d}, J=7.6 \mathrm{~Hz}, 3 \mathrm{H}) ;{ }^{13} \mathrm{C} \mathrm{NMR}$ (100 MHz, DMSO- $\left.d_{6}\right): \delta 173.9,136.5,133.1,131.3,121.1$, 68.3, 52.5, 49.9, 34.2, 29.5, 27.2, 24.1, 23.2, 22.1, 19.2; ESIMS: $\mathrm{m} / \mathrm{z}$ calcd $[\mathrm{M}]^{+}:$384; found: $385[\mathrm{M}+\mathrm{H}]^{+}$. HRMS (ESI): $\mathrm{m} / z$ calcd $[\mathrm{M}]^{+}: 384.3079$; found: $384.3085[\mathrm{M}]^{+}$.

Methyl $N$-pentanoyl- $N$ - $\{[2$ '-(1-trityl-1 $H$-tetrazol-5yl)biphenyl-4-yl]methyl\}-L-valinate (7). To a solution of 5-phenyl-1-trityl-1H-tetrazole (6) $(2.0 \mathrm{~g}, 5.15 \mathrm{mmol})$ in THF (20 mL), $n$-BuLi (2.5 M in hexane) $(2.5 \mathrm{~mL}, 6.18 \mathrm{mmol})$ was added at $25{ }^{\circ} \mathrm{C}$ under a $\mathrm{N}_{2}$ atmosphere. The reaction mixture was stirred at $25^{\circ} \mathrm{C}$ for $1 \mathrm{~h}$ and then cooled to $-20^{\circ} \mathrm{C}$. Anhydrous $\mathrm{ZnCl}_{2}$ (1.25 g, $\left.9.27 \mathrm{mmol}\right)$ was added to the reaction mixture and then stirred at $-20^{\circ} \mathrm{C}$ for $30 \mathrm{~min}$. The reaction mixture was allowed to warm to $25{ }^{\circ} \mathrm{C}$. Aryl bromide $5(2.37 \mathrm{~g}$, $6.18 \mathrm{mmol})$ followed by Q-phos $(0.182 \mathrm{~g}, 0.25 \mathrm{mmol})$ and $\mathrm{Pd}(\mathrm{II}) \mathrm{OAc}(0.06 \mathrm{~g}, 0.25 \mathrm{mmol}$ ) was added to the reaction mixture. The reaction mixture was heated to reflux at $75^{\circ} \mathrm{C}$ for $2 \mathrm{~h}$. 
The reaction was monitored by TLC until the starting material was consumed. Water $(30 \mathrm{~mL})$ was added to the reaction mixture and extracted with ethyl acetate $(3 \times 50 \mathrm{~mL})$. The ethyl acetate layer was separated and concentrated under vacuum. The residue was chromatographed on silica gel. Elution with a mixture of heptanes and ethyl acetate (70:30) gave the title compound $7(2.84 \mathrm{~g}, 80 \%)$ as a white solid, mp $45-47^{\circ} \mathrm{C}, R_{\mathrm{f}}=$ 0.6 (7:3; heptanes/EtOAc), ${ }^{1} \mathrm{H}$ NMR (400 MHz, DMSO- $d_{6}$ ) $\delta 7.72(\mathrm{~d}, \mathrm{~J}=7.2 \mathrm{~Hz}, 1 \mathrm{H}), 7.60(\mathrm{~m}, 1 \mathrm{H}), 7.51(\mathrm{~m}, 1 \mathrm{H}), 7.42(\mathrm{~m}$, $1 \mathrm{H}), 7.36(\mathrm{~m}, 11 \mathrm{H}), 6.98(\mathrm{~m}, 1 \mathrm{H}), 6.88(\mathrm{~m}, 7 \mathrm{H}), 4.62(\mathrm{~m}, 2 \mathrm{H})$, $3.25(\mathrm{~s}, 3 \mathrm{H}), 3.17(\mathrm{~s}, 1 \mathrm{H}), 2.23(\mathrm{~m}, 2 \mathrm{H}), 2.01(\mathrm{~m}, 1 \mathrm{H}), 1.34(\mathrm{~m}$, $2 \mathrm{H}), 1.19(\mathrm{~m}, 3 \mathrm{H}), 1.01(\mathrm{~m}, 2 \mathrm{H}), 0.86(\mathrm{~d}, 3 \mathrm{H}), 0.74(\mathrm{~d}, 3 \mathrm{H})$; ${ }^{13} \mathrm{C}$ NMR (100 MHz, DMSO- $\left.d_{6}\right) \delta 173.8,170.9,170.6,164.0$, 141.6, 141.3, 139.1, 137.6, 130.9, 130.0, 129.3, 128.7, 128.3, $128.0,127.9,127.4,126.2,82.7,62.3,51.7,48.6,33.6,32.6$, 27.6, 22.5, 20.3, 19.7, 14.4; ESIMS: $\mathrm{m} / z$ calcd $[\mathrm{M}]^{+}: 691$; found: $692[\mathrm{M}+\mathrm{H}]^{+}$;

$N$-Pentanoyl- $N$ - $\{[2$ '-(1H-tetrazol-5-yl)biphenyl-4-yl]methyl $\}$ L-valine (8). To a solution of compound 7 (2 g, $2.89 \mathrm{mmol})$ in methanol $(20 \mathrm{~mL}), 3 \mathrm{~N} \mathrm{NaOH}(2.85 \mathrm{~mL})$ was added and the mixture heated under reflux for $6 \mathrm{~h}$. The progress of the reaction was monitored by TLC until the starting material was absent. The reaction mixture was concentrated under reduced pressure and the residue was diluted with EtOAc $(100 \mathrm{~mL})$ and distilled $\mathrm{H}_{2} \mathrm{O}(20 \mathrm{~mL})$. Hydrochloric acid $(2 \mathrm{~N} \mathrm{HCl})$ was added dropwise to the mixture until the $\mathrm{pH}$ reached 4.0. Then the organic phase was separated and the aqueous phase extracted with EtOAc $(3 \times 50 \mathrm{~mL})$. The combined organic extracts were dried over anhydrous $\mathrm{Na}_{2} \mathrm{SO}_{4}$. Evaporation of the solvent gave the crude product (1.12 g, 90\%). Recrystallization from EtOAc afforded the anticipated product valsartan 8; mp $114-118{ }^{\circ} \mathrm{C}$; ${ }^{1} \mathrm{H}$ NMR (400 MHz, DMSO- $d_{6}$ ): $\delta 12.6$ (brs, $\left.1 \mathrm{H}\right), 7.72(\mathrm{~m}, 4 \mathrm{H})$, $7.24(\mathrm{~m}, 1 \mathrm{H}), 7.15(\mathrm{~m}, 2 \mathrm{H}), 6.94(\mathrm{~m}, 1 \mathrm{H}), 4.58(\mathrm{~m}, 1 \mathrm{H}), 4.40$ $(\mathrm{m}, 1 \mathrm{H}), 3.33(\mathrm{~m}, 1 \mathrm{H}), 2.25(\mathrm{~m}, 1 \mathrm{H}), 1.52(\mathrm{~m}, 6 \mathrm{H}), 0.9(\mathrm{~m}, 3 \mathrm{H})$, $0.84(\mathrm{~m}, 3 \mathrm{H}), 0.74(\mathrm{~m}, 3 \mathrm{H}) ;{ }^{13} \mathrm{C}$ NMR $\left(100 \mathrm{MHz}, \mathrm{DMSO}-d_{6}\right)$ : $\delta 174.0,172.4,171.8,141.7,138.2,131.54,131.1,131.0$, 129.3,128.8, 128.2, 127.4, 126.7, 70.3, 63.4, 49.9, 32.9, 28.05, 27.3, 22.2, 20.6, 14.2; ESIMS: $m / z$ calcd $[\mathrm{M}]^{+}:$435; found: 436 $[\mathrm{M}+\mathrm{H}]^{+}$; HRMS (ESI): $m / z$ calcd $[\mathrm{M}]^{+}: 435.5187$; found: $435.5125[\mathrm{M}]^{+}$

\section{Acknowledgements}

We are grateful for the support of the Sardar Vallabhbhai National Institute of Technology, Surat and Indian Association for the Cultivation of Science, Jadavpur, W.B. India for analytical support.

\section{References}

1. Duncia, J. V.; Chiu, A. T.; Carini, D. J.; Gregory, G. B.; Johnson, A. L.; Price, W. A.; Wells, G. J.; Wong, P. C.; Calabrese, J. C.; Timmermans, P. B. M. W. M. J. Med. Chem. 1990, 33, 1312-1329. doi:10.1021/jm00167a007

2. Bühlmayer, P.; Furet, P.; Criscione, L.; de Gasparo, M.; Whitebread, S.; Schmidlin, T.; Lattmann, R.; Wood, J. Bioorg. Med. Chem. Lett. 1994, 4, 29-34. doi:10.1016/S0960-894X(01)81117-3

3. Wyvratt, M. J.; Patchett, A. A. Med. Res. Rev. 1985, 5, 483-531. doi:10.1002/med.2610050405

4. Carini, D. J.; Duncia, J. V.; Aldrich, P. E.; Chiu, A. T.; Johnson, A. L.; Pierce, M. E.; Price, W. A.; Santella, J. B., III; Wells, G. J.; Wexler, R. R.; Wong, P. C.; Yoo, S. E.; Timmermans, P. B. M. W. M. J. Med. Chem. 1991, 34, 2525-2547. doi:10.1021/jm00112a031

5. Negishi, E.; King, A. O.; Okukado, N. J. Org. Chem. 1977, 42, 1821-1823. doi:10.1021/jo00430a041

6. Nicolaou, K. C.; Bulger, P. G.; Sarlah, D. Angew. Chem., Int. Ed. 2005, 44, 4442-4489. doi:10.1002/anie.200500368

7. Fanta, P. E. Chem. Rev. 1964, 64, 613-632. doi:10.1021/cr60232a002

8. Miyaura, N.; Suzuki, A. Chem. Rev. 1995, 95, 2457-2483. doi:10.1021/cr00039a007

9. Oba, M.; Saegusa, T.; Nishiyama, N.; Nishiyama, K. Tetrahedron 2009, 65, 128-133. doi:10.1016/j.tet.2008.10.092

10. Zhang, C. X.; Zheng, G. J.; Bi, F. Q.; Li, Y. L. Chin. Chem. Lett. 2008, 19, 759-761. doi:10.1016/j.cclet.2008.04.032

11. Zhang, C.; Zheng, G.; Fang, L.; Li, Y. Synlett 2006, 3, 475-477.

\section{License and Terms}

This is an Open Access article under the terms of the Creative Commons Attribution License (http://creativecommons.org/licenses/by/2.0), which permits unrestricted use, distribution, and reproduction in any medium, provided the original work is properly cited.

The license is subject to the Beilstein Journal of Organic Chemistry terms and conditions:

(http://www.beilstein-journals.org/bjoc)

The definitive version of this article is the electronic one which can be found at: doi:10.3762/bjoc. 6.27 